\title{
The overview of Government subsidies to agriculture sector in India
}

\author{
Harshal A. Salunkhe ${ }^{1}$ Dr.B.B.Deshmush ${ }^{2}$ \\ ${ }^{1}$ Asst. Prof., Dept. of Business Administration SSBT's COET, Bambhhori, Jalgaon 425001(MH) India. \\ ${ }^{2}$ Principal, R.R. Senior College, Jalgaon 425001(MH) India
}

\begin{abstract}
The agriculture subsidies are integral part of the farmers life in India. The agriculture subsidies plays very important role in agriculture sector in every country. The every year's government of India spends lot of money in various agriculture subsidies for growth of agriculture sector. The total arable \& permanent cropland is 169,700 thousand hectors in India. The authors used only secondary data for research. This paper basically focuses on overview of agriculture subsidies in India with help of provisions of funds for agriculture in five years plans and annual budget. The authors also study types of agriculture subsidies and distribution criteria in India. Last few years the percent investment in agriculture sector is increases \& percent of agriculture subsidies is decreases in India. To know the percentage agriculture subsidies in developed countries and developing countries, also number of dependent on agriculture sector.
\end{abstract}

Keyword-Agriculture, Annual budget, Five years plan, Investment \& Subsidies

\section{Introduction}

Indian Government play vital role in agriculture sector development. The government role is diverse and varied. Some of the cited reasons for vital role are self-sufficiency, employment creation, support to smallscale producers for adopting modern technologies and inputs, reduction of price instability and improvement of the income of farm households. This vital role can take a number of forms such as import-export policies and domestic policies like price support programmes, direct payments, and input subsidies to influence the cost and availability of farm inputs like credit, fertilizers, seeds, irrigation water, etc. Of all the domestic support instruments in agriculture, input subsidies and product price support are the most common. Various benefits are cited in justifying input subsidies: economic, environmental and social (World Bank 2008). Input subsidies can bring economic benefits to society. Inputs like fertilizers, irrigation water and electricity have a significant share in agricultural subsidies in India and fertilizer subsidy has attracted much attention of policymakers, and researchers in the recent past. An agricultural subsidy is a governmental financial support paid to farmers and agribusinesses to supplement their income, manage the supply of agricultural commodities, and influence the cost and supply of such commodities. A subsidy, often viewed as the converse of a tax, is an instrument of fiscal policy. Derived from the Latin word 'subsidium', a subsidy literally implies coming to assistance from behind. The objective of subsidies, by means of creating a wedge between consumer prices and producer costs, lead to changes in demand/ supply decisions. The forms of subsidies are a cash payment to producers/consumers is an easily recognizable form of a subsidy. However, it also has many invisible forms. Thus, it may be hidden in reduced tax-liability, low interest government loans or government equity participation. If the government procures goods, such as food grains, at higher than market prices or if it sells as lower than market prices, subsidies are implied

\section{1) Review of Indian Agriculture Sector}

Indian agriculture has an extensive background which goes back to 10 thousand years. At present, in terms of agricultural production, the country holds the second position all over the world. In 2009, agriculture and it contributed $16 \%$ of the Gross Domestic Product of the country. In addition, the sector recruited about 52\% of the entire manpower.

In spite of the fact that there has been a gradual fall in its contribution to the gross domestic product of the country, agriculture is currently the biggest industry in India.

In terms of agricultural contribution, the following states in India are the most developed states:

Punjab, Uttar Pradesh, Madhya Pradesh, Haryana, Bihar, Andhra Pradesh, Maharashtra, West Bengal etc.

All these states play a key role in the agriculture development of India. The total arable territory in India is $1,269,219 \mathrm{~km}^{2}$, which represents about $56.78 \%$ of the overall land zone of the country. Arable land in India is diminishing because of continuous strain from an ever-increasing number of inhabitants and growing urbanization. The overall water surface area of the country is $31440 \mathrm{~km}^{2}$ and the country experiences a mean yearly precipitation of $1,100 \mathrm{~mm}$. Irrigation represents $92 \%$ of the consumption of water and in 1974, it was 380 
$\mathrm{km}^{2}$. India holds the second position in production of wheat, rice, cotton, sugarcane, and groundnuts. It is also the second biggest harvester of vegetables and fruit, representing $8.6 \%$ and $10.9 \%$ of the overall vegetable and fruit production in the world correspondingly.

\section{Review of literature}

The subsidy is very important for growth of farmers in India. Many persons have presented their views on agriculture subsidies in national \& internal national level through research papers \& articles

In case study of escalating costs of agricultural subsidies in India, published in Joint Learning Event: Promoting Pro-Poor Growth, Policy Instrument Note \# 1, Farm Input Subsidies author focus on costs of agricultural subsidies in India. India originally introduced subsidies on fertiliser, irrigation water and rural electricity - that drove many of the irrigation pumps - in the 1960s to support the successful drive for the green revolution. Indian production of the two main cereals, rice and wheat, accelerated notably after 1967. While studies confirm that payment of subsidies on inputs contributed to rapid expansion of production of cereals in the early phases of the green revolution, once fertilizer use had spread, then it is less clear that the subsidies contribute to further increased production. Moreover, since the early 1980s the costs of the subsidies have increased notably rising to between $15 \%$ and $25 \%$ of the government budget, more than is spent on education - in a country where adult literacy is only 61\%. Since the mid-1990s growth of agricultural production has slowed, apparently for lack of investment in physical infrastructure, research and extension. The fear is that the cost of the subsidies has crowded out other public investments.

In research paper of "Agricultural Subsidies in India Boon or Curse" by -Rajwinder Kaur \& Dr.Manisha Sharma is established relation between subsidies (including fertilizers, electricity and irrigation) distributed in zone \& productivity of zone in India. During pre as well as post liberalization periods, at country level as well as zone level, the total subsidies have increased in absolute terms, whereas at India level as well as in south, west, north, north-east zones, productivity has also increased except in 1996-97 and in east zone productivity has declined during 1996-97 to 2000-01. As compared to post-liberalization period (2006-07) with pre-liberalization period (1990-91), it is observed that in India, subsidies have increased 8.32 times, whereas productivity increased by only 1.1 times. While comparing the same time period, as zone level analysis shows that in west zone, subsidies have increased the maximum number of times i.e. 11.95 times, followed by south zone (8.93 times), east zone ( 7.67 times), north zone ( 7.49 times) and north-east zone (6.28 times), On the other hand productivity has increased maximum i.e. 1.90 times in south zone, followed by west zone (1.12 times), north zone (1.11 times), east zone (1.1 times) and north-east zone (1.05 times). In 1990-91, south zone has got near about three times of total subsidies and has near about two times of productivity; whereas in 2006-07, it has received 3.37 times of subsidies and has near about two times of productivity as compared to east zone.

III. Comparison of developing \& developed countries regarding Subsidies to Agriculture sector Table no.1 Comparison of developing \& developed country regarding Subsidies to Agriculture

\begin{tabular}{|c|c|c|c|}
\hline Country & $\begin{array}{c}\text { Subsidy per } \\
\text { hectare }\end{array}$ & \% subsidies & $\begin{array}{c}\text { Population dependent on } \\
\text { agriculture }\end{array}$ \\
\hline EEC & $\$ 82$ & $37 \%$ & $8 \%$ \\
\hline USA & $\$ 32$ & $26 \%$ & $5 \%$ \\
\hline Japan & $\$ 35$ & $72 \%$ & $4 \%$ \\
\hline China & $\$ 30$ & $34 \%$ & $24 \%$ \\
\hline South Africa & $\$ 24$ & $60.67 \%$ & $18 \%$ \\
\hline India & $\$ 14$ & $2.33 \%$ & $60 \%$ \\
\hline
\end{tabular}

Source-Compilations from WTO reports

The above table shows agriculture subsidies is global phenomenon and it percent is more in developed country and less in developing country. In European countries its percentage is more than India. The dependant on agriculture sector more in developing countries \& less in developed countries

\section{1) Investment in Agriculture Sector in India}

Capital investment in agriculture and allied sectors has witnessed a steadily increasing trend in recent years. It has risen from $13.5 \%$ in $2004-05$ to $20.1 \%$ in $2010-11$. This growth has been possible because of initiatives taken by the Government to make agriculture a sustainable vocation. Investment in public sector includes irrigation works, command area development, land reclamation, a forestation and development of state farms. Private sector investment includes construction activities including improvement/reclamation of land, construction of non-residential buildings, farm houses, wells and other irrigation works. The capital investment is measured in terms of Gross Capital Formation (GCF) relative to the country's Gross Domestic Product (GDP). As per Annual Report of the Department of Agriculture and Cooperation for the year 2011-12, GCF in agriculture and allied sectors in 2010-11 was Rs. 142254 crore. It was Rs. 76,096 crore in 2004-05. 
GCF in agriculture and allied sectors from 2004-05 to 2010-11 is represented in the following graph

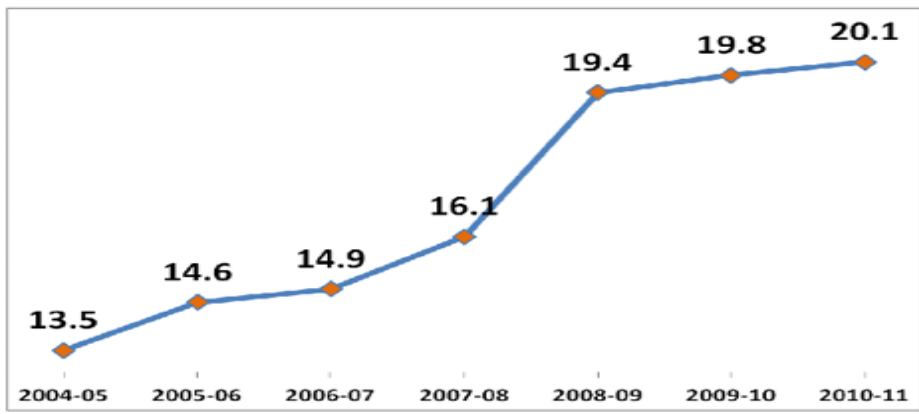

Sources-India Infoline News Service / 08:37, Apr 11, 2012

\section{The major agricultural subsidies, distribution criteria in India \& subsidies distributed in last few years}

There are major agriculture subsidies are subsidies on fertilizer, electricity and irrigation. In addition to this one more form which is intangible and uncountable is that, agricultural income is not taxed in India. These days the issue revolves around fertilizer subsidies more.

The subsidies can be distributed among individuals according to a set of selected criteria, e.g.
1) Merit
2) Income-level
3) Social group etc.

The study brings to the fore the massive magnitude of subsidies in the provision of economic and social services by the government. Even if merit subsidies are set aside, the remaining subsidies alone amount to $10.7 \%$ of GDP, comprising $3.8 \%$ and $6.9 \%$ of GDP, pertaining to Centre and State subsidies respectively. The average all-India recovery rate for these non-merit goods/services is just $10.3 \%$, implying a subsidy rate of almost $90 \%$.

Distribution of Total Subsidies \& Gross Cropped Area in India (1980-81 to 2008-09)

Table no.2

\begin{tabular}{|c|c|c|c|c|c|}
\hline $\begin{array}{c}\text { Subsidies/ } \\
\text { Years }\end{array}$ & $\begin{array}{c}\text { Fertilizers } \\
\text { (In Rs. } \\
\text { Crores) }\end{array}$ & $\begin{array}{c}\text { Electricity } \\
\text { (In Rs. } \\
\text { Crores) }\end{array}$ & $\begin{array}{c}\text { Irrigation (In } \\
\text { Rs. Crores) }\end{array}$ & $\begin{array}{c}\text { Total } \\
\text { Subsidies (In } \\
\text { Rs. Crores) }\end{array}$ & $\begin{array}{c}\text { Gross } \\
\text { Cropped Area } \\
\text { (In 000 } \\
\text { hectares) }\end{array}$ \\
\hline $1980-81$ & 471.88 & 357.56 & 399.10 & $1,228.54$ & $1,73,324$ \\
& $(38.41)$ & $(29.10)$ & $(32.49)$ & $(100.00)$ & \\
\hline $1985-86$ & $1,804.80$ & $1,324.15$ & $1,667.21$ & $4,796.16$ & $1,77,526$ \\
& $(37.63)$ & $(27.61)$ & $(34.76)$ & $(100.00)$ & \\
\hline $1990-91$ & $4,638.56$ & $4,621.00$ & $3,917.41$ & $13,176.97$ & $1,85,403$ \\
& $(35.20)$ & $(35.07)$ & $(29.73)$ & $(100.00)$ & \\
\hline $1996-97$ & $8,148.41$ & $15,594.00$ & $10,404.73$ & $34,147.14$ & $1,88,601$ \\
& $23.86)$ & $(45.67)$ & $(30.47)$ & $(100.00)$ & \\
\hline $2000-01$ & $13,724.05$ & $26,904.00$ & $14,711.71$ & $55,339.76$ & $1,86,565$ \\
& $(24.80)$ & $(48.62)$ & $(26.58)$ & $(100.00)$ & \\
\hline $2008-09$ & $1,01,180.68$ & $14,771.52$ & - & $1,15,952.20$ & $1,75,678 *$ \\
& $(87.26)$ & $(12.74)$ & & $(100.00)$ & \\
\hline
\end{tabular}

Source: (1) Government of India, Fertilizers Association, Fertilizer Statistics, various issues, New Delhi.

(2) Government of India, State Electricity Boards, Annual Reports, Various Years.

(3) Government of Punjab, Statistical Abstract, Various Years

Note: Percentages are shown in parentheses * above information is Year-2006-07(Gross Cropped Area)

Above figures shows the total amount of subsidies is increases year by year. In 1980-81 total amount was Rs.1, 228.5 crore \& in year 2008-09 is 1, 15,952.20 crore. In year 1980-81 gross cropped area was 1, 73,324 hectares, it was increase up to $1,88,403$ hectares \& again it was decrease in year 2006-07 up to $1,75,678$ hectares. At same time population in India is increases in year 1980-81 was 68.52 crore, 84.39 crore in 1991, 102.70 crore in $2001 \& 121$ crore in 2012 . These all things clearly show that agriculture subsidies increases from 1980-81 to 2008-09 \& gross cropped area is likely to be same but population of country gradually increases. 


\section{Agriculture under the Five-year Plans \& annual budget}

\subsection{Agriculture under the Five-year Plans}

Before the planning period, agriculture was in a deplorable condition. The farmers were generally in heavy debt to the village money-lenders. They were having small and scattered holdings. They had neither the money nor the knowledge to use proper equipment, good quality seeds and chemical fertilizers. Except in certain areas, they were dependent upon rainfall. Productivity of land as well as of labour had been declining and was lowest in the world. In spite of the fact that nearly $60 \%$ of our working population was engaged in cultivation, the country was not self- sufficient in food grains but had to depend on food imports. Table 1 gives the total outlay for each plan and correspondingly the outlay on agriculture and irrigation had also increased with every plan.

Table no.3: Plan Expenditure on Agriculture and allied Sectors, Irrigation (Rs. In Crore)

\begin{tabular}{|c|c|c|c|c|}
\hline 5 Years Plan & $\begin{array}{c}\text { Total plan } \\
\text { Expend. }\end{array}$ & $\begin{array}{c}\text { Agri. \& allied } \\
\text { sectors }\end{array}$ & Irrigation & $\begin{array}{c}\text { \% of total } \\
\text { outlay }\end{array}$ \\
\hline $1^{\text {st }}$ plan & 1960 & 289.9 & 441.8 & 37.3 \\
\hline $2^{\text {nd }}$ plan & 4671.8 & 549 & 541.6 & 23.3 \\
\hline $3^{\text {dr }}$ plan & 8576.5 & 1088.9 & 1019.1 & 24.6 \\
\hline $4^{\text {th }}$ plan & 15778.8 & 2120.4 & 2415.7 & 28.7 \\
\hline $5^{\text {th }}$ plan & 39426.2 & 4864.9 & 3925.8 & 22.3 \\
\hline $6^{\text {th }}$ plan & 109291.7 & 6623.5 & 10929.9 & 16.1 \\
\hline $7^{\text {th }}$ plan & 218729.6 & 12792.6 & 16589.9 & 13.4 \\
\hline $8^{\text {th }}$ plan & 485457.2 & 24895.7 & 31398.9 & 11.6 \\
\hline $9^{\text {th }}$ plan & 941041 & 37239 & 67875 & 11.2 \\
\hline $10^{\text {th }}$ plan & 152563.9 & 58933 & 103315 & 10.6 \\
\hline
\end{tabular}

Source-Indian Agriculture under the Five-Year Plans, Booklet No. 539, Agricultural Situation in India: ASIS-10

The above figures show that percent of fund allocation in five years plans for agriculture sector is decreases and fund allocation for industry \& other sector increases. The growth agriculture sector only $4 \%$ from last few years and contribution of agriculture sector in GDP is decreases that's why need of separate agriculture budget for India

\subsection{The Allocation of funds for agriculture sector in Annual budget Year 2010-11 to 2012-13 in India}

Agriculture retained its high priority in budget with a planned allocation for agriculture \& allied sectors raised by $19 \%$ to INR 176.9 billion ( $\$ 3.5$ billion). The budget provides additional funds to several ongoing for enhancing agriculture production, irrigation management, higher farm credit \& improving post-harvest storage $\&$ processing infrastructure

Table no.4 India: Selected Agriculture \& Food-Related Budget Item Ministry of Agriculture (Rs in Billion)

\begin{tabular}{|c|c|c|c|c|}
\hline & $\begin{array}{c}\mathbf{2 0 1 0 - 2 0 1 1} \\
\text { Actual }\end{array}$ & $\begin{array}{c}\mathbf{2 0 1 1 - 2 0 1 2} \\
\text { Budget }\end{array}$ & $\begin{array}{c}\mathbf{2 0 1 1 - 2 0 1 2} \\
\text { Revised }\end{array}$ & $\begin{array}{c}\mathbf{2 0 1 2 - 2 0 1 3} \\
\text { Budget }\end{array}$ \\
\hline Crop Husbandry & 98.13 & 78.91 & 74.31 & 90.34 \\
\hline Soil and Water Conservation & 0.14 & 0.15 & 0.16 & 0.16 \\
\hline Animal Husbandry & 7.15 & 9.50 & 7.50 & 10.63 \\
\hline Dairy Development & 0.85 & 2.23 & 1.84 & 3.53 \\
\hline Fisheries & 2.91 & 2.70 & 2.83 & 3.00 \\
\hline Forestry and Wildlife & 9.29 & 7.85 & 7.82 & 9.07 \\
\hline Plantations & 4.74 & 4.15 & 4.39 & 4.46 \\
\hline Food, Storage and & 5.02 & 6.44 & 6.34 & 7.87 \\
\hline Warehousing & & & & 28.98 \\
\hline Agricultural Research and & 25.22 & 24.92 & 25.70 & 1.25 \\
\hline Education & & & & 17.64 \\
\hline Co-operation & 1.03 & 2.22 & 16.48 & $\mathbf{1 7 6 . 9 2}$ \\
\hline
\end{tabular}

Source-GOI Budget 2012-13 - Agricultural Highlights

The above figures show that agriculture expenditure in annual budget is decreased year by year. This thing is responsible for slow growth rate for agriculture sector \& less contribution in GDP of India. 


\section{Conclusion}

India has very huge arable area and lot of investment in agriculture in last few years. But there is large number of decrement was shows in provision of fund towards agriculture sector in five years plan and annual budgets in accordance with agriculture subsidies. The amount of agricultural subsidies is increasing year by year but at the same time total cultivated agricultural land \& investment also increasing. This above thing is responsible for slow growth of agriculture in India and less contribution in GDP of country.

The agriculture subsidies are distributed by every country but its percentage is very low and numbers of dependent is very large in India. The government of India took serious measures for development of agriculture sector and agriculture subsidies are one of vital tool to help for growth of agriculture sector in India.

\section{References}

[1] http://en.wikipedia.org/wiki/Agriculture in India

[2] http://en.wikipedia.org/wiki/Subsidies_in_India

[3] A Train4Dev / OECD DAC POVNET Joint Learning Event: Promoting Pro-Poor Growth, Policy Instrument Note \# 1, Farm Input Subsidies 23 June. 09.* FEWSNET reports of MoAFS estimates published By OECD http://www.oecd.org/dac/povertyreduction/47466700.pdf Page No.8

[4] Rajwinder Kaur1 , Dr.Manisha Sharma Sep-Oct. 2012 "Agricultural Subsidies in India Boon or Curse" in IOSR Journal of Humanities and Social Science (JHSS) ISSN No-: 2279-0837, ISBN: 2279-0845, Volume- 2 Issue- 4, page no.43 \& 46

[5] L.N.S. Prasad, WTO norms \& Indian agriculture published by Indian liberal group http://www.liberalsindia.com/freedomfirst/ff449-03.php page no.2

[6] Capital investment in agriculture rises to 20\% in India Infoline News Service / 08:37 , Apr 11, 2012http://www.indiainfoline.com/Markets/News/Capital-investment-in-agriculture-rises-to-20-percent/5393178406

[7] Government of India, Fertilizers Association, Fertilizer Statistics, various issues, New Delhi.

[8] Government of India, State Electricity Boards, Annual Reports, Various Years.

[9] Government of Punjab, Statistical Abstract, Various Years

[10] Dr. K. T. Chandy--Indian Agriculture Under the Five-Year Plans, Booklet No. 539, Agricultural Situation in India: ASIS-10 Page No.2

[11] HarshalA.Salunkhe, (JULY 2012) “A Separate Agriculture Budget for India-Need of the hour" Referred International journal of Commerce, Economic \& Management (ISSN No. 2231-4245) (online journal) volume no. 2 issue no. 7 page no.146 \&147

[12] GOI Budget 2012-13 - Agricultural Highlights, USDA Foreign agriculture services, Global Agriculture Information Network, Date12/03/2012 GAIN Report No.-IN2042 (Voluntary- Public) page no. 2 \& 3 